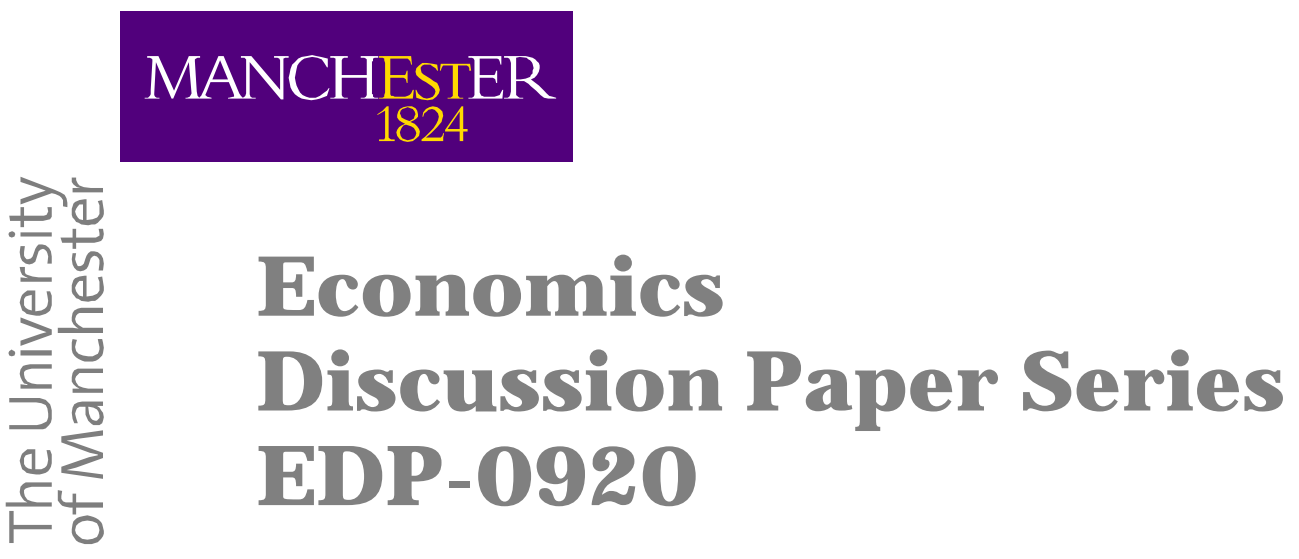

\title{
Regulation and Corruption in Transitional China
}

Xiaobing Wang

October 2009

Economics

School of Social Sciences

The University of Manchester

Manchester M13 9PL 


\title{
Regulation and Corruption in Transitional China
}

\author{
Xiaobing Wang ${ }^{1}$
}

\begin{abstract}
Whilst China has, over the past thirty years, had a poor quality legal system and a high level of corruption it has also had high rate of economic growth. This is puzzling for those holding the conventional view that both poor institutions and corruption are bad for growth. This paper attempts to address this puzzle by studying the interaction between corruption and regulation by examining two positive effects of corruption on growth. First, economic reform depends on the support of those who have economic power. Polices that allow government departments and officials to divert resources from the planned track to the market track, and allow them to undertake private businesses make them part of the driving force for reform. This also creates an enormous potential for large amounts of institutionalized corruption, which it is impossible to curb without the regulations being changed. This kind of corruption can be viewed as providing compensation to these institutions and officials in exchange for them giving up some of their power to market. This first mechanism facilitates reform. Second, large amounts of bad regulations exist in transitional economies. Certain kinds of corruption can actually keep bad policies and regulations from being fully implemented and thus support growth. They enable people to break the status quo when institutions are bad. These kinds of corruption are not a hindrance to the economy, but can be seen to be convenient devices for overcoming regulatory hurdles that distort incentives and prevent business opportunities. Although China has many laws and regulations which are bad for growth, China also has high level of corruption, part of which offsets the bad effects of these laws and regulations and makes these bad laws less harmful for growth. The dynamics of the relationship between regulation and corruption is also discussed. We conclude with the argument that being tough on corruption at the early stage of development could stifle potential development. This argument runs counter to the conventional view of the importance of using anti-corruption measures as a part of a development strategy.
\end{abstract}

Keywords: Regulation, Corruption, Growth, China.

JEL classification: D72, D73, D78, O11, O41.

\footnotetext{
${ }^{1}$ Economics, SoSS and Centre for Chinese Studies, The University of Manchester, Oxford Road, Manchester M13 9PL. Email: xiaobing.wang@manchester.ac.uk, Tel: +44 (0) 161275 4871. This paper was presented at the Third Meeting of the Initiative for Policy Dialogue Task Force on China on Regulation at the University of Manchester, June 25-26, 2008. The author would like to thank participates of the meeting and Nick Weaver for comments and suggestions. Of course, all errors are mine.
} 


\section{INTRODUCTION}

China's GDP has grown very significantly during the last few decades, averaging around $10 \%$ per annum since the reforms began in 1978. China's legal system and institutions, including investor protection systems, corporate governance, accounting standards, and quality of government, are significantly less developed than many other countries in the world (Allen, Qian and Qian, 2005). At the same time China is perceived as one of the more corrupt countries. According to the 2007 Transparency International Corruption Perceptions Index, China is ranked $72^{\text {nd }}$ in the world with a score of $3.5^{2}$. Pei (2007) argues that China's level of corruption is one of the highest in the world which ever measure is used. It is widely accepted in the growth literature that both poor institutions and corruption are bad for growth. A common argument is that a poor legal system and corruption distorts market incentives and thus hinders economic growth. Why is China an exception to this or how do we explain the co-existence of poor regulation, high corruption levels and a high growth rate? This is puzzling.

The neo-classical view supports small governments and low levels of regulation. To them, the market can correct itself and most government regulations distort market incentives and reduce welfare. However, many (for example, Amsden 1989, Wade 1990) believe that government policies and regulations play a significant role in economic development. Stiglitz (2008) gives three fundamental reasons for the need for government intervention: market failures caused by asymmetric information and externalities, people's irrational behaviour, and distributive justice.

It is clear that good regulations and industrial policies may reduce transaction costs, avoid market failures, help the optimal allocation of resources and enhance economic growth and justice of a country, but it is not clear that how a country can avoid bad regulations and guarantee good ones? In many cases, government's temptations to correct market failures make things worse. It is undeniable that there are many badly designed laws and government regulations in many economies.

There are three sources of bad laws and regulations.

i) Bad government gives rise to bad regulations.

Some governments come into power not through the democratic process and thus may not represent people's interests (such as a dictator and his government), some governments may follow political or religious ideologies, such as communist ideology. These governments make laws and regulations not according to the optimum level of production in the economy but according to their own economic and political interests. Laws and regulations in these countries may reflect the optimum level of the ruler group but will not necessarily reflect the optimum level of the whole economy and its people.

ii) Government has good objectives but makes mistakes.

\footnotetext{
${ }^{2}$ A country or territory's CPI Score indicates the degree of public sector corruption as perceived by business people and country analysts, and ranges between 10 (highly clean) and 0 (highly corrupt).
} 
Another cause of bad laws and regulations is the low level of governments' intellectual capacity. In many cases governments intended to help their countries develop but were unable to find good strategies and good regulations to support this. The level of economic development of a country is correlated with the government's ability to provide market supporting institutions (North and Thomas 1973; North, 1990). However, the ability of the state to provide market supporting institutions and regulations is constrained by the state's capacity and the level of development (Besley and Persson 2007). We cannot simply assume that the laws and regulations are always optimal. In many less developed countries, there are many badly designed government regulations behind which lay good intent. Good government objectives do not always yield good regulations because of intellectual capacity constraints. When states capacity is low, it tends to have either less "good" regulations needed to support the market or too many "bad" regulations that hinder market development, or both!

iii) Governments still use old regulations that no longer suit new situations.

In a changing world, laws and regulations need to be updated to fit the new situations, but it takes time for government and law makers to learn and respond properly. Before these laws and regulations are changed, they may restrict people from exploiting business opportunities and thus hinder economic development. For transitional economies, the institutions and regulations were originally designed for the planned economic system and public ownership. These institutions and regulations may have been suitable for the old system but are unlikely to be appropriate in the new environment. It takes time for the government and regulatory bodies to learn about the market mechanism.

For whatever reasons, so long as there are bad laws and bad regulations, it is bad for economic growth if they are fully implemented. However, if corruption works as a counterforce to these bad regulations, the economy is free from the influence of these bad laws and regulations, as if they did not exist.

This paper studies the interaction between corruption and regulations, it examines two mechanisms that could explain why China's corruption is less harmful than others or even may have helped the economic growth in someway. This is one of the few studies that looks at the positive effects of corruption on growth and is the first that examines the interaction of corruption and regulations. It does not intend to survey everything but to present certain regulations and forms of corruption, their interactions and the impacts on the economy. It focuses on how the negative effects of regulation might be overcome or minimized by certain forms of corruption.

There are two mechanisms at work. First, economic reform depends on the support of those who have economic power. Polices that allow government departments and officials to divert resources from the planned track to the market track, and allow them to undertake private businesses creates an enormous potential for large amounts of institutionalized corruption, but also make them part of the driving force for reform. This kind of corruption can be viewed as providing compensation to these institutions and officials in exchange for them giving some of their power up to the market. Second, large amounts of bad regulations exist in transitional economies. Certain kinds of corruption 
can actually keep bad policies and regulations from being fully implemented and enable people to break the status quo and thus support growth. This can be seen to be convenient devices for overcoming regulatory hurdles that distort incentives and prevent business opportunities. These kinds of corruption are not a hindrance to the economy, but facilitate reform and economic growth in China. In these cases, not only is corruption impossible to curb without the regulations being changed, but also being tough on corruption at the early stage of development could stifle potential development.

Whilst the idea that corruption can facilitate economic development is not new the breadth of this phenomena emphasised by this paper is. The normal way to look at the positive impact of corruption is through ideas such as the so-called "speed money" hypothesis of corruption. In this literature the emphasis is on bad regulations, so called "red tape". It generally includes the filling out of seemingly unnecessary paperwork, obtaining of unnecessary licenses, having multiple people or committees approve a decision and various low-level rules that make conducting one's affairs slower and/or more difficult. "Corrupt transactions between private and public agents are a means of circumventing cumbersome and pervasive regulations (red tape) that are detrimental to efficiency. This argument - an application of the theory of the second best - views bribery and other forms of kickback, not as any hindrance to the economy, but as convenient devices for overcoming institutional hurdles that distort incentives and opportunities" (Blackburn and Forgues-Puccio, 2007).

This paper is organised as follows: section 2 examines the interaction between some regulations and institutionalised corruption. It shows how some corruption may in fact facilities the reform process by means of illustrative examples. Section 3 describes more examples in the situation some corruption helps overcome some of the bad regulations and is therefore good for the economic growth. Section 4 concludes the paper with a discussion of the evolution of the relationship between regulation and corruption and offers some policy implications.

\section{REFORM AND INSTITUTIONALISED CORRUPTION}

This section discusses a mechanism explaining connections between regulation and corruption: some regulations create corruption and some are embedded with corruption. It tries to answer the following question: How did corruption come to be generalized by some regulations? What are the impacts of this corruption on the economy?

It is clear, after 30 years of reform, that China has moved from being a planned economy to a market oriented one. This was not clear in the beginning of the process. The reform was pushed by some leaders, like Deng Xiaoping, as a way of escaping from the disaster of the Cultural Revolution. Which way to go and how to reform was not clear at all at that time. There was no blueprint at the early stage of the reform. The approach China took was a trial-and-error experiment, which in Deng's words, involved "crossing the river by feeling for stepping stones". 
Before 1985, resource allocation in China was done mostly under the plan via the planning bureaucracy. In the early 1980s, the Chinese government relaxed bureaucratic control over resource allocation by allowing state owned firms to produce and sell outside-plan output directly to buyers at "floating prices." The outside-plan prices were initially regulated by the government and not allowed to exceed plan prices by more than 20 percent. On January 1, 1985, the government lifted the control on outside-plan pricing. Markets for outside-plan products then developed rapidly in China in parallel to the existing plan ( $\mathrm{Li}, 2002)$. So in the beginning, the emerging product market (the market track) coexisted with the traditional central planning (the plan track) and as means of resource allocation. This hybrid economic system was the result of the so-called the dual track reform.

Under the dual-track system, an identical good would often be allocated on both the plan track and the market track. But the good would typically be sold at a substantially higher price in the market than in the plan. Officials who had discretion over the allocation of inplan resources could and allegedly did divert in-plan resources to the market and pocket the profits. Under "the dual-track system, the hallmark of the Chinese reform, was widely believed to have fuelled a particular form of corruption-diversion of underpriced in-plan goods to the market by officials" (Li, 2002). This type of corruption was widely known in China as "Guandao" or official diversion and was one of the big reasons for the discontent that led to the 1989 Tiananmen Square Demonstration. However, this corruption did not necessarily negate the improvement in allocative efficiency in the Chinese economy brought about by the reform. Li (2002) found that the distortions brought about by official diversion from the planned track to the market track (which is a corruption) might have mitigated partially the existing distortions under the plan and resulted in an improvement in economic efficiency in China.

Though the reform was gradual and incremental, there were huge obstacles to reform and there were uncertainties about whether it was going to succeed and be sustained. Although the direction was not clear, the overall trend was reducing direct planning and restraining government power and letting markets play bigger and bigger roles. Where ever this market oriented reform restrained the power of the government and government officials, it faced huge resistance especially from those government departments and officials, whose power and interest was likely to be negatively affected or reduced by the reform. Many government officials had high social and economic status prior to reform; they had to be compensated for the loss of that in the reform if it was to gain their support. Without their support the momentum of the reform could have quickly faded out. To make the reform self-enforcing, and irreversible, it was felt by those pushing for the reforms that more people should be involved and those in power that could lose in the reform should be compensated. As well noted by Fan and Grossman (2001), "In this environment the transformation of local officials from unproductive political entrepreneurs to productive economic entrepreneurs has been critical to the success of Chinese economic reform..."

In the first stage, governments departments and the army were given the power to create and own enterprises; this meant that they were given the right to exchange power for 
economic interests. At the start of the 1990s bureaucrats were given permission to set up businesses in China. As early as 1993 there were 900,000 administrative enterprises engaged in commercial activities ( $\mathrm{Li}$, Smyth and Yao 2005). These were profit-making enterprises set up by government institutions.

There were also many administrative enterprises that "not formally affiliated with government institutions; nor were they run by incumbent government officials. However, many of the chief executives running these enterprises were former government officials who continued to maintain close financial, administrative and personal ties with their former government institutions. These entrepreneurs, though without former cadre titles, relied on their cadre background and networks to navigate the business sea and earn big profit." (Gong 1997, p285)

The decision to let government institutions set up businesses was claimed by the reformers to be aimed at reducing the size of the bureaucracy and boosting private enterprise. But in reality this was a deliberate policy that aimed at involving government departments and officers in business so they would facilitate and support the reforms. There were many such exchanges of public power for personal interest. This can be described as a type of corruption: corruption as a policy, institutionalized and deliberate. This policy that included the government officials as part of the interest group who would benefit from reform in return for their support, made reform gain momentum and become irreversible and self-enforcing. Those who lost power through reform have been compensated economically.

As reform has progressed, many state owned enterprises (SOEs) lack competitiveness became evident. As Lin, Cai and Li (2003) argues, these firms were often set up for strategic propose, supported by government. Once subsides were cut off, these firms lost their viability in the market. Many of the former SOEs were either not produce according to their comparative advantage, or employing far too many people, or not producing the right products for the market. In late 1980s and 1990s, many of these firms were set for privatization. In 1988 there were only 90 thousand private enterprises in China, while by 2007 , this number had increased to 5.5 million. In this process, there was a huge amount of corruption in the valuation of these firms' assets, and who was able to acquire them. Although the privatization of these firms was far from being fair in terms of a redistribution of the wealth and thus caused moral problems, it also, to some extent, had a huge growth effect. Unviable and non-profitable enterprises were transformed into profitmaking ones. The private sector grew much faster than the public sector and provided most of China's growth. This is partly because the private sector had incentives to bribe and get things done, while the state sector stuck to the law and did not worry too much about performance.

Some regulations institutionalize corruption and this corruption induced further reform. So there are growth effects of corruption in China. The key architecture of the reform, Deng Xiaoping's philosophy was that of balance between corruption and economic growth. Less attention was given to social justice. Distributional concerns gave way to economic performance. Some people were able to get public assets illegally, but this was 
tolerable so long as they improved efficiency. The sale of SOEs, even if it meant an unfair redistribution of national wealth and created huge moral problems, it increased economic efficiency by turning non-performing state owned enterprises into profit making private enterprises. And this was a net gain for the economy.

Allowing government agencies or offices to operate private businesses made them the driving force of the reform. This approach of reform created institutionalised corruption, which was impossible to curb and resulted in a very high level of corruption. However, this was for the sake of economic growth. This runs against the conventional corruption literature. Corruption is much more than a redistribution of income from the government to corrupt officials, it is also likely to have growth effects. As noted by Fan and Grossman (2001), "Local officials are often de facto managers in China. In the dual-track economy, local officials continue to play a critical role in coordinating production and exchange. The more income that an efficient but corrupt local official generates for his region, the more he can appropriate for himself while still leaving enough fruits of progress for ordinary people to assuage their natural jealousy of his privileged position." If we only look at the surface without digging beneath it into the sources of this corruption, then one would be puzzled to explain the co-existence of high growth and high corruption levels. It becomes more obvious when the mechanisms are revealed.

There are many administrative controls and incomplete regulations in the transition from a planning system to a market oriented one. In the midst of the transition, central government had not yet established mechanisms for preventing the abuse of these controls. This gave huge opportunities for corruption, and to a great extent, this corruption is institutionalised. Because corruption is institutionalised, it is impossible to curb by severe punishment of individuals. This explains why many successors to certain positions still carry on the corruption of their predecessors, even though their predecessors were imprisoned or even executed.

When corruption is institutionalised, it can only be solved by reforming these institutions and regulations, which takes time. Corruption is so pervasive that it is impossible to punish all of the civil servants that are corrupt. Only selective punishment can be used in practice. As Fan and Grossman (2001) agree, this strategy is consistent with the Chinese Communist Party's strategy.

\section{BAD REGULATIONS AND GOOD CORRUPTION}

Corruption is commonly defined as the abuse of public office for private gain, including bribery threats and kickbacks, in ways that violate laws and other formal regulations. Traditional corruption literature presumes the benevolence of laws and taxations. It assumes that the laws and regulation set up by the government reflect the optimum level of production and hence support economic growth. Any kinds of distortion as a result of corruption, either a compromising of the enforcement of laws or tax evasion, will drive the economy away from the optimum level of production and will negatively impact on the economy. However, as discussed in the previous section, this starting point should not be taken for granted in many countries. We can not simply assume that the laws and 
regulations put forward by governments reflect the interest of the people and economic development. Few would doubt the fact that misgovernance is widespread and that there have been detrimental consequences of this for development and growth.

Corruption works as one of the mechanisms that makes it difficult for governments to enforce laws. Corruption is commonly regarded as a way of undermining the legitimacy of government and government regulations, but what if the government regulation itself neither has legitimacy nor reflects the optimal level of growth in the first place? If regulations are bad and constrain economic activities, avoidance of these regulations may be good for economic development.

In the case of bad regulations, their full implementation would hinder growth. If those bad regulations had been removed earlier, then the economy would have grown faster. However, a government's ability to make good regulations is constrained by the level of economic development. The improvement in the quality of regulations has been very difficult and slow. In a transitional economy like China, even when the government has the wish to develop the economy, the laws and regulations they pass often hinder growth.

Before the reform, China was a fully planned economy. In 1978 there were total of 83,000 state-run factories, plus 100,000 urban collectives and 700,000 rural collectives. Although China's planning was not as all encompassing as was the case in the Soviet Union, the number of "planned commodities" was about 800 in China in 1978 compared with many thousands in the Soviet Union. China undertook a speedy transition and by 1993, planned prices had ceased to apply to most goods.

As in many transition economies the existing economic institutions and regulations in China which were created for the previous planned economic system and for public ownership persisted when that system was no longer operating. The old system had excessive government involvement in production and other economic activities. In the new environment with reduced planning, the continuation of the old regulations allowed government continue to control and intervene in the economy, leaving little space for people's own decision making and thus restricting their potential to undertake economic activities. Some of the inherited old laws and regulations actually become obstacles to the functions of market and required reform. But until they are reformed, the strict implementation of these bad laws and regulations may actually harm the economy.

Socialist laws were not designed for market oriented growth. But when the economy began the transition, those laws remained in force. Why did China not change these outdated laws and regulations straight away? One reason is that there were too many and they were too pervasive to change them all at once. The approach of simply abolishing the old system without properly establishing a new system is one which has proven to be problematic as witnessed by the failures of the Shock Therapy in the former Soviet Union and East European countries. The approach China has taken is for reform and transition to be gradual (Lau, Qian and Roland, 2000). 
After the Cultural Revolution, people realized the great need for reform and change. But just as with the medical treatment of a patient, one needs to know how the patient will respond to the treatment required. In this context the question was how the economy would be likely to respond to the kind of markets that might emerge. The gradual implementation of markets gave time to see how the patient was responding. During the reform period, old laws and regulations are in constant change and revision, new laws and regulations being set up continuously: the whole legal and government system being in constant evolution. The Chinese Communist Party and the government lay behind all these changes with its aim being to push the economy towards a market oriented system.

When revising or abolishing these old laws and regulations the government is constrained by it's intellectual capacity. This is especially true in a country in which hostility to the market was strongly embedded. People had very limited knowledge of how markets work and how growth might be promoted by the market. The revision of the old laws and regulations depended on people's knowledge about market systems. The process of discovering which regulations are good and which are bad takes time, and which order regulations should be reformed in or which new regulations should be set up first in order to promote economic growth is not obvious.

Because of the transitional nature of the reform period, we should not simply assume that the laws and regulations in existence are optimal. There are two kinds of laws and regulations that in force but may actually hinder economic growth: those inherited from the old system which do not support the market, and many new laws and regulations that were passed during the reform period but actually restrains economic activities because of the constrains on the government's capability or because of conflicts of interest between government departments. Because governments have limited knowledge of market institutions and market regulations, it takes time for government to realize the negative effects of new laws and regulations, and it takes time to reform them. Although it is clear now that some laws and regulations were obstacles to the functions of market, and should have been reformed earlier, but at the time the government was still feeling its way and learning about the market. The Government did not know due to lack of information about what should be reformed and how it should be changed.

When the government is unable to change laws and regulations with sufficient speed to promote the required level of growth, one option is for people to find ways round the constraints imposed by these laws and regulations. Corruption is one of the means by which these bad regulations can be circumvented and the economy be allowed to enjoy the fruits of less regulation at the micro level. Of course, not all the negative effects of bad regulations can be cancelled out by corruption and corruption itself may create some problems such as social injustice and moral problems. Some forms of corruption, like the acquisition of monopoly power by certain business might have net negative effects on growth. But those kinds of corruption, that get around bad regulations and generate positive growth effects, are our main focus here. One example of such a bad law is an overly aggressive corporate tax rate which discourages private economic activities. Bribery, in exchange for some tax evasion, may make it possible for a business to survive, grow and flourish. 
Let us now discuss some examples that show some aspects of bad regulations and how corruption can get around them to improve economic outcomes.

\subsection{Corruption as a way of getting round the slow speed of regulatory reform}

It takes time for people to recognize and reform bad regulations. Under the planning system, free trade was not allowed. For some period during the culture revolution (19661976), activities such as growing an apple tree or raising some chickens at home were considered capitalist and were forbidden in many places. Trade that followed from such activities had to be undertaken on the black market. When families did not get enough food from their collective, they were forced to go out to buy grain at night to avoid being caught. These extreme policies were reduced but to some with a few vestiges even in the reform period. In the "Criminal Law of The People's Republic of China", which was issued in 1979, buying at a cheaper price from one place and selling at a higher price in another (now considered very normal business practice) was a criminal offence. These kinds of activities were described as "Touji Daoba" (speculation), and it was stated that a wide range of goods, ranging from "important production materials" to "some durable consumer goods", were not to be traded privately. In 1987, a detailed legal explanation and guidance for the implementation of this law came into force. This guidance was called the "Provisional Guidance of Administrative Punishment on Touji Daoba". In 1993, when the decision had been made that China was to become a market economy, this law and this provisional Guidance which restricted market behaviour were still in existence. Although the enforcement of this law and the Guidance almost disappeared in the later stage of reform, it was only in 1997 that the criminal offences associated with the law were abolished in name and it was only in January 2008, that "Provisional Guidance of Administrative Punishment on Touji Daoba" was finally abolished.

In the early 1980s in China, private enterprises were not allowed to enter many sectors or engage in many economic activities. Buying and selling grain was controlled by the government and the private sector was only allowed to do this in late 1990s. There are still many policies even now in China, which by western standards might be regard as hindering economic growth. These need to be changed but still have not been reformed. China's regulations at the end of the $20^{\text {th }}$ century still prohibited private business in 30 sectors and restrict private business in 20 more (Sachs, Woo and Yang, 2000).

There were many laws and regulations that based on pure political ideologies. The label Private Entrepreneur had big political implications at the beginning of the reform period. According to Marx's categorisation, in the mid $19^{\text {th }}$ century, if a person hires less than eight workers, then he would lie in a category between the "capitalist" and the "worker" and could be described best as an individual entrepreneur. If eight or more people were employed, the owner of the firm might be said to be "exploiting" his worker's surplus value and he could best be described as a capitalist. At the beginning of the reform, worries about this exploitation were a big issue. Many people paid bribes to officials to avoid persecution for exploitation, but many people were fined and imprisoned because they hired eight or more workers and fell into the category of capitalist exploiter. 
Nowadays, although these arbitrary categorise are still written in law, different categories still face different tax rates and different legislative obligations, people have some freedom to choose to register as individual entrepreneurs or private enterprises when they start their business.

\subsection{Corruption as way of getting round governments' intellectual capacity constraints}

The lack of capability of those undertaking the reforms not only affects the reform of the old laws but also influences new legislations. These capabilities are limited by lack of knowledge of how markets work and how markets respond to interventions. Many laws and regulations passed, even in the reform period, late proved poor and needed revision. The One Party political system makes it easy to pass a law without proper scrutiny and often fails to see possibly adverse side effects.

An income tax law was passed in 1980 in China, with the tax threshold set at 800 Yuan a month, 20 times higher than the average monthly wage at that time of 40 yuan. This rate did not change until 2006, when the benchmark income for taxation was increased to 1600 Yuan. This new benchmark is slightly higher than the average monthly wage in China. The problem is that the requirement to pay tax was not seriously implemented. Urban residents rarely paid any income tax at all. Many employers, like big state-ownedenterprises (SOEs), government departments, and universities, with wages much higher than this threshold managed to avoid or reduce paying tax by negotiating a private tax rate with the local tax bureaucracy, and/or paid only a small part of the wage through banks but a larger proportion through cash or other channels to avoid tax. It is so prevalent that almost all employers from ministry level to small private businesses evade income taxes in this way. Almost everybody in China knows this, but few argue against it. For an individual or an institution a good relationship with the tax bureaucracy is crucial for economic well being. The paying of bribes and kickbacks to the tax bureaucracy and individual officials in the tax bureau is common practice.

Why is this possible, and why do so many people and even government turn a blind eye on this seemingly very severe and damaging problem? There are many reasons, first the tax threshold is so low and secondly, there is no capital gains tax in China. If someone make hundreds of thousands of Yuan in the stock market and does not pay anything, why should anyone pay taxes on their wage income? The inconsistency of the tax liability for the people across sectors and regions means the tax law is not perceived of as being fair. Its existence means that at any point in time bureaucrats can use the law in an arbitrary fashion, imposing the law unless they receive bribes. This fosters huge corruption.

With the incompetence of the higher level of government to initialized change, in the beginning, the reform was in many respects a bottom-up process. Many ordinary people and low level government officials were the first to break the status quo. The higher leadership was more worried about being criticized for pursuing "capitalism". It was only with the success of these low level changes that the higher leadership felt confident enough to recognise these developments as formal policy. For example in the late 1980s 
and early 1990s, Guangdong province was short of grain. Private trading in grain was not allowed and it was very difficult to get permission from central government for crossprovince trade through the official channels (planning track). Some private entrepreneurs started to trade grain on the black market, and the success of this quickly meant that it grew to a very large scale. According to Guo Rongchang, the former party leader of Guangdong province, the provincial party committee decided not to intervene in black market grain trading, when the central government refused to permit free trade and freely floating grain prices in Guangdong province. He explained "we were in a very difficult situation (dilemma), we cannot change central government's policy, and on the other hand, we can not afford not to consider people's voices. ... We neither disobeyed the central government, nor suppressed the people; we just turned a blind eye. After sometime, this black market turned public gradually, and central government agreed to give-up the price control gradually.” (Southern Metro News, 22 September 2008)

3.3 Corruption as a way to avoid damaging conflicts of interest between different government agencies

China at the beginning of the reform was a far less centralized economy than the Soviet Union and the East European economies were then. China's decentralized structure made it possible for many government bodies to create laws and regulations. There were often many different laws, acts, regulations from different levels of the legislative system and different levels of government (the province, county, town, even village, and different departments of the governments.). They all tended to consider their own interests and this often meant higher taxes and fees, especially coming form the level of local government. Many of these taxes and fees can be considered as examples of bad regulations because they increased transaction costs and hampered economic activity. However, even though central government wanted to abolish these, to do so has proven to be difficult.

Agricultural taxation is a good example. The agriculture tax was a liability on all rural residents simply because they lived in rural areas and it was assumed they were involved in agricultural production although in many cases they were not. Agricultural taxes were due by every citizen that had been allocated a piece of land regardless of whether this was farmed. This tax had regionally differentiated rates and it was to some extend affordable. However, in addition to this tax, there were many other taxes levied on the rural population: various fees and administrative charges. These charges had to be paid to the various level of government include villages and communes for social welfare, infrastructure and management and to the township for education, family planning, paramilitary support, infrastructure and irrigation. However, most of the services which were supposed to follow from these taxes were never received by the taxpayers or the work was not done, despite payments having been made (Knight and Song, 1999).

Many levels of governments and government departments had interests in charging fees for various services. Overall, there have been hundreds of different kinds of taxes and fees imposed on farmers by various levels of government and organisations. In order to relieve farmers' financial burdens, central government explicitly abolished and forbade many such fees and charges, but local governments sought ways round these restrictions 
on their behavior. This took the form of assigning new names to these fees and charges names different from the ones that had been abolished by the central government. Central government introduced the "fees-for-tax plan" in early 2000, which simplified the tax system substantially. Under this plan farmers were only required to pay the agricultural tax, the special agricultural product tax and a strictly limited number of additional taxes. Despite this effort rural peasants were still heavily taxed and exploited.

Official figures (China Statistic Yearbook) suggest that farmers' per capita income grew around 4\% per year after 1996, a rate of income growth far below that of urban residents or of GDP as a whole. This resulted in an increasing urban-rural income gap. Per capita income earned by urban dwellers was 250\% that of rural residents in 1998, and by 2002 this gap was $330 \%$. Social unrest in rural areas rose to a historical high in 2002. As a result of this in 2004, the central government decided to abolish all rural taxes and fees, leaving less opportunity of local government to carry on with their previous practices.

Things improved significantly, but still much needs to be done. According to a report by the People's daily (22 September 2008), the official newspaper of CCP, Feicheng town, in Henan province passed an administrative order that required a certificate and deposit before farmers could harvest their corn, and sent hundreds of officials to farmlands to enforce this order. This was despite the fact that "the Administrative Permission Law of the Peoples Republic of China" clearly states that no government lower that the provincial level has right to pass administrative regulations. The town governor explained the purpose of this regulation as "to prevent the burning of corn stems and to encourage compost fertilising". However, this can hardly stands. Environmental concerns may be just an excuse of imposing fees, because the problem was not that law required farmers to be fined if they burnt the corn stem but rather that they had to pay a deposit even before they could harvest their own corns in their own land. The amount of the deposit often exceeded the total worth of corn in the field. After many complaints and widespread media reporting, this administrative order was abolished and the local governor was sacked. However, according to the Legal Daily $30^{\text {th }}$ October 2007, similar events had already occurred previous to this in some counties in Hebei province. The lessons from then had not been learned.

Although the development of the legal system was given high priority in the reform period, China's judicial system is still struggling with the details of implementation. The emergence of a new legal system suitable for the market has been accompanied by the growth of corruption as a form of networking (Guanxi). This Guanxi has developed to complement laws such as contract law in an environment where such laws are not clear, not enforceable or not deemed useful. The enforcement of contracts has often had to rely on personal relationships with the government officials. It is well known in China that it is difficult to get a judge's decision to be acted upon. People win a lawsuit but in many cases nobody will execute it. They have to pay a fee to the court for the court to enforce the verdict, but whether they would do it, or the time scale within which the court does it is up to the court to decide. Bribery is undertaken not only to influence judge's decision making but also to influence the execution of those decisions. 
To sum up, for the business sector, in an exogenously given and heavily regulated environment, as is the norm in transition economies, when there is no endogenous power and opportunities to speedily influence the reform of these regulations and controls, corruption may act as a way to escape from these regulations.

Although there is still a net loss in efficiency, when compared with the situation of no bad regulation, the corruption may actually prevent a greater loss of efficiency when the bad regulations are exogenously given. So, given that a country has bad regulations, an economy may gain from this kind of corruption. In the presence of bad regulations and misgovernance, corruption can also provide net gains to the economy, acting as a counter-force to the bad institutions.

\section{CONCLUSIONS AND POLICY IMPOLICATIONS}

The paper examines two kinds of mechanisms, both closely related to regulation and corruption in transitional China. It does not argue for and encourage corruption. Rather it attempts to document what is and the arguments are, based on the belief that second best may be best when the first best is not available. When there are badly designed laws, without corruption, these laws may restrict growth. Then high levels of corruption might be counteracting the negative effects of these bad regulations and thus provide an explanation for the coexistence of bad regulations, high levels of corruption and high economic growth. This explains why pervasive corruption in China is not as damaging as some might suspect it would be. In fact much of the corruption may actually be progrowth.

When addressing economic development, close attention should be paid to the quality of regulation. Though severe corruption can cause severe problems, more attention should be given to the causes of corruption, rather than just try to curb the corruption as it is. Is the corruption caused by lack of regulation, or over regulation or inappropriate regulation? Curbing corruption without looking at the rationale of the regulations is meaningless. If corruption is generalized by government regulation, it becomes institutionalized and is very difficult to curb. In this case, ccorruption is deeply embed in the regulatory setting, and the temptation to try to curb corruption without changing the regulatory soil that nourishes it, is likely to fail. Being tough on corruption may reduce some of the support for reform and would leave no chance for people to escape from bad regulations. Efforts put into curbing corruption might be better used to improve institutions and regulations.

The conventional view, of attempting to eliminate corruption as a development strategy in order to overcome the prevalence of "government failure" in the third world, may need to be reconsidered. As this paper reveals much corruption is not the source of poor governance and regulations, but rather the result of it. Being tough on corruption will not only be unable to solve many development problems, but also potentially will divert scarce resources away from tackling real problems.

In a system where laws are "anti-growth", corruption sometimes is good for growth. In a system where the laws are "pro-growth", corruption is likely to have more negative effects and thus should be controlled. When countries are poor, they tend to have more 
poor regulations which hinder growth. In such cases, corruption may be necessary to counter the bad regulations if growth is to occur. When a country develops, the state capacity, including its intellectual capacity, increases, bad regulations will gradually become reformed and become less and less prevalent. With the decrease of the proportion of bad regulations, the proportion of good corruption is likely to decrease and the proportion of bad corruption likely to increase. Corruption then should be of greater concern. It is only then that a tough anti-corruption strategy is likely to not only increase fairness but also have positive effects on economic growth. It is also only then that governments will have begun to develop sufficient audit and inspection capabilities to allow the corruption to be effectively controlled.

It is clear that China is moving towards a market oriented economic system and the transition is so far relatively smooth. The reform in China is self-enforcing and has become irreversible. Along with development, the state capacity including its intellectual capacity and management skills are increasing, and China is more and more likely to be able to reduce its bad policies and regulations, and hence corruption. 


\section{References}

Allen, Fanklin., Jun Qian and Meijun Qian, 2005, "Law, Finance, and Economic Growth in China", Journal of Financial Economics, 77: pp57-116.

Amsden, Alice H. 1989, Asia's Next Giant: South Korea and Late Industrialization, New York: Oxford University Press,

Besley, Timothy., and Torsten Persson, 2007, The Origins of State Capacity: Property Rights, Taxation, and Politics, LSE mimeo.

Blackburn, K. and G.F. Forgues-Puccio, 2007. Why is corruption less harmful in some countries than in others? CGBCR working paper series no.088

China Statistic Yearbook, various years, National Bureau of Statistics of China (eds.), Beijing: China Statistics Press.

Fan, Chengze. and Herschel Grossman, 2001, "Incentives and Corruption in Chinese Economic Reform", Journal of Economic Policy Reform, Vol. 4, pp.195-206.

Gong, T., 1997, "Forms and Characteristics of China's Corruption in the 1990s: Change with Continuity", Communist and Post-Communist Studies, 30: 277-88.

Knight, J. and L. Song 1999. The Rural-Urban Divide: Economic Disparities and Interactions in China. Oxford, Oxford University Press.

Lau, Lawrence, Yingyi Qian, and G'erard Roland (2000), "Reform without Losers: An Interpretation of China's Dual-Track Approach to Transition," Journal of Political Economy, 108:120-143.

Legal Daily, 30 ${ }^{\text {th }}$ October 2007 “Certificate Required to Harvest Corn in Cheng' an Hebei Province". (in Chinese language)

Li, Ke., Russell Smyth, and Shuntian Yao, 2005, "Institutionalized Corruption and Privilege in China's Socialist Market Economy: a General Equilibrium Analysis", Pacific Economic Review, 10 (3): pp 341-360.

Li, Wei, 2002, "Corruption during the Economic Transition in China," in Donatella Della Porta and Susan Rose-Ackerman (eds.) Corrupt exchanges: Empirical Themes in the Politics and Political Economy of Corruption, Chapter 9, pp. 160-177, Nomos Verlag. Germany.

Lin, Justin Yifu, Cai, Fang. and Li. Zhou., (2003), The China Miracle: Development Strategy and Economic Reform. Hong Kong: Chinese University Press 
North, Douglass C. and Robert Paul Thomas, 1973, The Rise of the Western World: A New Economic History. New York: Cambridge University Press.

North, Douglass C., 1990, Institutions, Institutional Change and Economic Performance. Cambridge: Cambridge UniversityPress.

Pei, Minxin, 2007, “Corruption Threatens China’s Future”, Policy Brief, No. 55, October.

People's daily, 22 September 2008, "Certificate Required to Harvest Corn”. (in Chinese language)

Sachs, J., T.-W. Woo and X. Yang, 2000, "Economic Reforms and Constitutional Transtition", Annals of Economics and Finance 1: 260-74.

Stiglitz Joseph, 2008, Government Failure vs. Market Failure: Principles of Regulation, IPD, Columbia University, Mimeo.

Southern Metro News, 2008, 22 September. "Oral history on 30 years of reform." (in Chinese language)

Wade, Robert., 1990, Governing the Market: Economic Theory and the Role of Government in East Asian Industrialization. Princeton: Princeton University Press. 